Não é saber apenas como aplicar um artigo de código, um artigo de lei, uma norma contratual, mas precisa saber bolar esquemas novos, precisa saber conceber esquemas jurídicos que possam atender às necessidades do comércio exterior. No trecho da conferência que o dr. Lobo não pôde ler há uma frase que eu gostaria de citar aqui, porque acho realmente muito instrutiva e muito útil para o advogado em geral, o advogado de empresa, o advogado de comércio exterior.

Diz o dr. Lobo: "A imaginação do comerciante sempre foi criadora e fértil; a ela devemos quase todos os institutos do direito marítimo, o título de crédito, a limitação da responsabilidade do sócio, a sociedade anônima e uma longa série de instrumentos da vida econômica. Em direito comercial é muito nítido que os institutos jurídicos precedem a lei. Não é a lei que os cita; a lei vem depois para disciplinar, às vezes restringindo indevidamente, o que a imaginação empresarial já criou e colocou em prática".

Eé exatamente a capacidade jurídica de entender essa realidạde econômica, de entender esses mecanismos novos, que deve ser ponto básico da função que o advogado tem a desempenhar. Na vida contemporânea, se quisermos transpor essa experiência do mundo medieval, tivemos a criação, pelo empresário financeiro, pelas instituições financeiras e sociedades de crédito e financiamentos, da letra de câmbio. A letra de câmbio com a sociedade de crédito e financiamentos é diferente da letra de câmbio tradicional e foi, entretanto, o mecanismo adequado que essas instituições conceberam, para evitar a incidência da Lei de Usura, para se defenderem da inflação e para dar rentabilidade aos aplicadores.

Ponto importante da conferência do dr. Lobo é a análise sobre o projeto de viabilidade, porque, mais uma vez, sentimos nitidamente o entrelaçamento das funções do advogado dentro do campo das relações internacionais. 0 dr. Lobo modestamente não quis mencionar que esse projeto de viabilidade foi uma tentativa de grande sucesso há alguns anos, uma experiência altamente frutuosa no Rio de Janeiro, do Centro de Estudos e Pesquisas de Ensino do Direito - CEPED, em que o dr. Lobo, após programa de estudo das sociedades comerciais, fazia a apresentação desse estudo de viabilidade, no qual, ao mesmo tempo que o advogado aplicava os conhecimentos de economia e finanças recebidos durante o curso, criava um sistema jurídico necessário para executar e concretizar o projeto de viabilidade. Então, nós teríamos a fórmula de compor os conflitos de interesse entre vários sócios, entre os vários acionistas, a forma de organização de uma jointventure, de uma sociedade anônima, ou qualquer que fosse o mecanismo estabelecido para levar à frente o projeto de viabilidade. Eaí mais uma vez se vê justamente a importância da função do advogado e do papel que ele deve desempenhar no campo do comércio exterior, segundo também observa, com tanta autoridade, o professor El Kosheri.

\title{
O projeto na história do financiamento internacional
}

\author{
Cleantho Paiva Leite, ex-diretor executivo do \\ Banco Interamericano de Desenvolvimento - \\ BID e consultor privado.
}

Simplificadamente, podem ser identificadas três etapas da evolução do projeto no quadro do financiamento internacional.

Na primeira, temos o financiamento internacional de dois tipos: sem projeto nenhum, o simples empréstimo a país, como o empréstimo que o Brasil herdou de Portugal quando teve que assumir a independência, quer dizer, não havia qualquer projeto para obter aquele empréstimo. Entretanto, os projetos eram lançados no mercado para obtenção do

\section{Cleantho Paiva Leite}

financiamento. Todos se lembram, por exemplo, do projeto para o financiamento do Canal do Panamá, o financiamento de Suez, o financiamento das estradas de ferro nos países do Terceiro Mundo. Havia projetos com maior ou menor grau de seriedade, inclusive com contribuição para o vocabulário internacional; e o projeto começou a aparecer sob uma forma característica dessa primeira etapa do financiamento internacional.

\section{A segunda etapa do financiamento internacio-}


nal é a em que predominam as grandes instituições financeiras nascidas depois de Bretton Woods. Após a Segunda Grande Guerra aparecerem três tipos de instituições financeiras, a saber, o Banco Mundial e todas as cópias de instituições de desenvolvimento nos países do Terceiro Mundo; os bancos de desenvolvimento; e os bancos de financiamento das exportações como: Eximbank, Ermez, CCFAZ, Export and Credit Garantee Sistems, na Inglaterra, etc. Registram-se financiamentos de programas meio assistenciais ou não, tipo Plano Marshall, AID, programas de cooperação dentro da Commonwelth, dentro da União Francesa, etc. Nessa segunda etapa, evidentemente, o projeto atinge o auge. Condição básica para a obtenção de financiamento nas instituições financeiras era a apresentação do projeto com estudo de viabilidade, com cash-flow, de preferência numa moeda que aparecia sacrossanta, o dólar.

A terceira etapa do financiamento internacional coincide com o mundo pós-OPEP, o do mercado do eurodólar, do financiamento à base do projeto, e está afetado hoje pela invasão de eurodólares, que chegaram ao mercado e, como o professor Sadek El Kosheri demonstrou, colocaram o Banco Mundial como instituição de financiamento relativamente secundária, isto é, o fluxo de financiamentos obtidos hoje no mercado de eurodólares é infinitamente superior aos recursos que são canalizados através das instituições clássicas de financiamento internacional na base de projetos.

De modo que, nessas três fases de financiamento internacional, ligeiramente recapituladas, poderíamos talvez falar - para tomar um título de um livro de Salvador Magalhaga El alvia delclínio - do projeto com o mecanismo de obtenção de financiamentos internacionais. Essa visão histórica, creio que tem certa importância porque há grande fluidez nas relações econômicas internacionais e nós estamos assistindo, a cada dia, a imaginação dos comerciantes - a que se referia Alberto Venâncio - que inventaram as sociedades anônimas, os títulos de crédito, etc., a inventar novos mecanismos de mobilização de recursos financeiros internacionais que ficam disponíveis ora aqui, ora ali, ora em países exportadores de petróleo, ora em países exportadores de alimentos, etc.

\section{Financiamento do balanço de pagamentos}

Sílvio Hitoshi Yanagawa, consultor jurídico do Banco Central do Brasil

Estamos realmente atravessando fase muito difícil para as nossas exportações e há dificuldade ainda maior para conseguirmos financiamentos no mercado internacional.

Temos observado nos últimos tempos que, mais do que o agravamento da balança comercial, o balanço de pagamentos tem sido onerado pelos juros e serviços da dívida. Acredito que poderíamos evitar uma situação mais grave para os países do Terceiro Mundo, em geral, na medida em que pudéssemos obter financiamentos mais fáceis, ou melhor, menos caros.

Conforme já foi frisado aqui várias vezes, o mercado de eurodólares é que tem prevalecido como fonte de financiamento do balanço de pagamentos de vários países. Ora, esse é um mercado que gira em torno de taxas de juros de prime-rate, ou de li-

\section{Sílvio Hitoshi Yanagawa}

bor. E são taxas muito altas que, para os projetos de longa maturação, não podem ser aplicadas, uma vez que o retorno do capital é demorado e custoso.

Ora, temos projetos de cuja viabilidade jamais poderíamos duvidar, como o Projeto Carajás, o Projeto do Cerrado, e outros. Então, acredito que, uma vez que as fontes institucionais estão sendo esgotadas e os recursos são curtos, essa tentativa de fazer intercâmbio entre países do Terceiro Mundo, contexto em que se registra a colaboração venezuelana e a dos Fundos Árabes, é, sobremodo, interessante. E creio, como advogado, ainda, que foi muito interessante essa exposição do Fundo Árabe para evitar a incidência de juros, recorrer a outros instrumentos que não envolvessem a cobrança de juros. Eé nesse sentido que os advogados devem trabalhar, usando imaginação, desenvolvendo a construção jurídica, trocando experiências. 